\title{
Exploring the gender effect on the pattern of EFL teacher-student interaction
}

\author{
Navabfard, Faezeh $\measuredangle$ \\ Islamic Azad University, Najafabad Branch, Iran (faeze.navab@gmail.com) \\ Rezvani, Ehsan \\ Islamic Azad University, Isfahan (Khorasgan) Branch, Iran (rezvani_Ehsan_1982@yahoo.com)
}

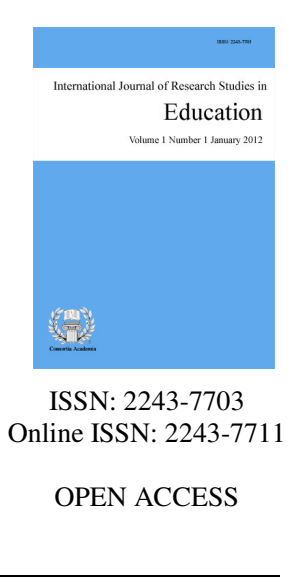

\section{Abstract}

The present study sought to investigate the effects of gender on interactional patterns of Iranian EFL classroom. Participants were 120 male and female EFL upper intermediate learners who were chosen from different language institutes in Isfahan, Iran. Besides, 12 teachers participated in the study in four types of classes: female teachers in single-gender classrooms, male teachers in single-gender classrooms, female teachers in mixed-gender classrooms and male teachers in mixed-gender classrooms. Tsui's Framework of discourse speech acts was employed as the instrument. Plus, patterns of interactions were investigated according to teachers' question types. In so doing, frequencies of subcategories of 'initiating' category in framework, referential and display questions were calculated for four types of classes. Findings indicated that, firstly, distributions of components of interactional patterns of initiation and types of questions were not fair. Secondly, mixed-gender classes included more effective patterns than single-gender classes. Thirdly, both male and females teachers paid more attention to the opposite gender in the classrooms. Findings of this study can be taken into account by teachers, especially those in mixed-gender classes that pay equal attention to both genders.

Keywords: gender; classroom discourse; patterns of interaction; EFL classrooms; types of questions 


\section{Exploring the gender effect on the pattern of EFL teacher-student interaction}

\section{Introduction}

Classroom discourse has several features that distinguish it from casual conversations in other interactive contexts. Many of these features relate to the teacher's role and power (Lin, 2007). Many factors are discussed about the classroom environment but one central argument could be the behavioral differences between male and female learners, and the reflection of gender-based social divisions in such interactions. TESOL classroom researchers have shown increasing interest in examining gender-related patterns of behavior in their work. This interest draws on and contributes to a burgeoning literature on gender and language. It is important, however, to bear in mind that gender related patterns dovetail with all the other dynamics of language behavior: Ethnic, class, regional, and age differences all affect speaking styles, along with such influences as sexual orientation, professional training, and individual personality.

Language is one of the most significant features and targets of gender issues, a separate field of language and gender led to the modern Women's Movement started to develop in the late 1960s (Sunderland, 2006). Its emergence and burgeoning development from emphasizing sex or gender differences (e.g. Lakoff, 1975; Spender, 1980) to the fluid, dynamic and complex nature of gender and performance and negotiation of gender identities or relations (e.g. Romaine, 1999; Talbot, 1998; Simpson, 1997; Eckert \& McConnell-Ginet, 1992) appear to further accelerate the surging demand for gender studies in other fields, particularly those closely related ones, for example, second language learning.

Classroom interaction is one of the primary means by which learning is accomplished in classrooms. Through their interactions with each other, teachers and students construct a common body of knowledge. There is evidence of renewed interest in the nature of classroom talk and signs of willingness to reassess the pedagogic value of interaction patterns between students and teachers in the language classroom, since learning a language in the classroom is a consequence of the exposure of the learner to the linguistic environment manifested in the interaction between the participants, namely teacher and students, in that context. Such interaction has been defined as a process whereby two or more people engage in reciprocal action (Celce-Murcia, 1987).

The role of interaction in second language learning has been emphasized in the field of SLA. Researchers had been widely accepted and proved that teachers initiate more contacts with males than with females and they criticize and praise males more often than females. As Sadker (1999) said, "classroom interactions between teachers and students put males in the spot-light, and relegate females to the sidelines, or to invisibility". So, these inequalities and gender bias exist in classes, although it has to be avoided in the world of education. Consequently, it is important that this area of study receives the attention it deserves.

According to Constantinou (2008, p. 28) "re-addressing the gender issue and seeking ways to better understand the phenomenon is a crucial step toward educational equity". As a result, it can be claimed that one of the important factors in studying the classroom interaction which is worth discussing is gender. The issue of gender and classroom interaction is important because it affects students' immediate educational and social experience, and has consequences for their future behavior and life outcomes. Researchers believe that a teachers' gender influences how they interact and communicate with their students (Constantinou, 2008). Therefore, this study aims to investigate the patterns of interaction which are affected by students' gender and whether teachers interact differently by gender with their students within an EFL context. 


\section{Review of Literature}

\subsection{Classroom Discourse}

Discourse has been largely described as the use of language inside social contexts (Gee, 2001). Nevertheless, the concept of discourse has complete complexity in meaning. Gee (2001) described discourse as a relationship among “acts, words, beliefs, values, attitudes and social identities" (p. 526) within a number of individuals who contribute with each other for the development of meaning and sense-making. He continues that discourse is greater in scope than classroom discussion. In other terms, it is a complicated contact between teacher and students, these individuals' exclusive perceptions is demonstrated in verbal communications. In specific, interactions between teachers and students have the ability to form the students learning improvement (Van den Oord \& Rossem, 2002). Verbal communication between students and teachers in classrooms forms the learning setting by affecting the sort of talk that students involve in during the teaching process (Gee, 2001).

Classroom discourse has a great number of characteristics that recognize it from unplanned discussions in other communicating contexts. Lots of these characteristics are in terms of teacher's authority and role (Lin, 2007): (1) the children's participation in the discourse through assigning turns, initiating most linguistic exchanges and having the right to the third movement is controlled by teachers; (2) teachers have improving educational aims that is essential to be followed in the discourse; (3) teachers propose the role of main knower and guide the discourse in a pre-selected path.

\subsection{Teacher's and Student's Roles in Dialogic Classroom Discourse}

As Bakhtin's (1986) notes, free space for student replies are created by dialogically organized instruction, accommodating and eliciting the divergent values, viewpoints of the conversant, beliefs and ideally containing the voices of different classes, ages, races and genders. Dialogically organized instruction is fueled by such pluralism and heteroglossia; the extent of social interaction clearly shapes both instruction and learning. When classroom interaction is dialogic, the balance of discourse is more symmetrical than in monologic discourse so that the teacher's voice is one voice among many, which is a critically important one. Yet repeated empirical results have demonstrated that monologic discourse which is predominant across American classrooms obviously recommends that monologic discourse is controlled within the classroom. The teachers play a main role in moving classroom into dialogic modes because of their exceptional roles in the classroom; this needs both persistence and skill.

Both teachers and students play specific roles for dialogic explosion. First, it is 'teacher moves' which means preparing the options for dialogic discourse. Authentic teacher questions and instances of uptake organize especially much dialogic interaction in classrooms intentionally. As much as these strategies prime the potentialities and excel the possibility of dialogic interaction, they may be regarded as ways that teachers "scaffold" (Bruner, 1978; Cazden, 1980) discussion.

\subsection{Gender}

Gender pierces all of our life and it impacts on our insights of others (Chavez, 2001). The concept is in terms of biological sex and almost always it greatly concerns with its underlying cultural and social meanings (Romaine, 1999; Pavlenko \& Norton, 2004; Sunderland, 2006). Romaine (1999) as one of the gender researchers offers complete explanations on the impact of gender on our life. According to some other researchers, gender is certainly a communicative manner which leads to directories or evidences such as fashion styles, physical appearance, language and behavior. Those directories suggest significant means for us to recognize ourselves and others as women or men and they might differ in cultures, communities and even time. Owing to the occurrence and significance of gender, rising consideration on gender subjects can even be found in the part of educational research. 
The notion which is needed to be considered is that there are many ways in which gender can be influential on development and language use into investigating the role of gender on the acquisition of language. A variable that can affect acquisition and language use as an outcome of psychological, biological effects or socio-cultural changes is gender. Bialystok (1979) proposed that language learning approaches are supposed to play an essential role in learning a foreign or second language, as they might support learners in learning the functions and forms are prerequisite for production or reception in the foreign or second language therefore imposing impact on accomplishment (cited in Hashemi, 2012).The term electronic dictionary (ED) is supposed to utilize for referring any reference material saved in electronic arrangement that provides information on spelling, meaning, or words usage. Therefore a spell-checker in a word-processing program, a tool which scans and interprets written words, a word list for on-line teaching materials, or an electronic form of a related hard-copy dictionary are all EDs of a type, categorized by the similar system of packing and retrieval.

\subsection{Studies on the Role of Gender in EFL Contexts}

Many factors are discussed about the classroom environment but one central argument could be the behavioral differences between male and female learners, and the reflection of gender-based social divisions in such interactions. One of the little-researched areas in teaching English as a second language is how a student's sex might affect teacher-student interaction in an adult EFL classroom (Duffy, Warren, \& Walsh, 2001). The research published from the 1960s to the 1990s demonstrate that the society and teachers expectations frequently lead to unfit behavior of female and male students in pre-college and college-level classrooms (Good \& Brophy, 1990; Sadker \& Sadker, 1992). Additionally, behaviors and faculty attitudes have been originated to have a deep consequence on a student's intellectual expansion, specifically for female students (El-Khawas, 1980).

It has been commonly supposed that sex is an influential issue in the process of student/ teacher interactions in the classroom. The research published from the 1960s to the 1990s specified that teachers' behavior toward female and male students in pre-college and college level classrooms is not equal (Sadker \& Sadker, 1992; Tannen, 1991). The college teachers have been found to ask male students higher-order questions demanding serious assumption (Sadker \& Sadker, 1992), make eye interactions more often with males than females (Thorne, 1979), permit their classrooms to be more frequent male-surrounded through calling on males (Thorne, 1979), permit males to interfere females (Hall, 1982), and reply to males with attention and females through varieties (Hall, 1982). Teachers of both sexes also regularly give male students further communication time than female students (Sadker \& Sadker, 1992) and ignite less contact with female students rather than male students. The classroom interactions between teachers and students put males in the highlight and demote females to the sidelines or to hiddenness as Sadker (1999) said. Moreover, doing a meta-analysis of 81 educations about the sex varieties in teacher-student interaction, Kelly (1988) determined that teachers tended to interact less with girls than boys in student and teacher started interaction. Teachers asked boys much more questions and offered them further chances to reply. In addition, Kelly came to the conclusion that teachers totally throw further attention to boys than girls, this fact is available in a great deal of classroom contexts containing ESL and EFL contexts. Steady with the further attained outcomes, Spender (1982) also found her classroom connections with gender bias. She was spending a minimum of $58 \%$ of her classroom time through cooperating with boys and a maximum of $42 \%$, and an average of $38 \%$, of her time with girls.

The teacher's sex also is influential on the classroom setting (Pringle \& Canada, 1995; Hatzichristoo \& Hopf, 1999; Duffy, Warren, \& Walsh, 2001). Teachers with dissimilar genders have classes with different features based on the studies that have been done in this area. For instance, the overall features of a class trained by a male teacher had quicker paces, sudden subject changes, much (excessive) teacher floor time and shorter, but more often, student trips. Female teachers were described as communicative facilitators and perhaps more tolerant of first language use. Female teachers were also defined as too forceful in selecting subjects and requesting a great number of questions mainly through intending smooth and continuing the informal movement (Chavez, 2000). 
Exploring the gender effect on the pattern of EFL teacher-student interaction

Unlike all these varieties among male and female teachers' manners in the classroom, Doray (2005), Rafiee Rad and Rashidi (2010), in their studies of classroom interaction in Iran and Australia, showed that female and male teachers had several conditions in common in terms of their designs of classroom discourse, maintaining the idea that the opportunity of discourse condition was dependent initially on the context and the role of mutual interaction.

\subsection{Research Question}

The present study attempts to answer the following question:

$>$ How is the pattern of teacher-student interaction shaped in Iranian upper-intermediate classes when the teachers and students belong to the same/different gender?

\section{Method}

\subsection{Participants}

The participants of this study were 120 upper-intermediate (60 female and 60 male) and 12 teachers in EFL conversation classes in different language institutes in Isfahan. Students were chosen from adolescent and adult classes and the mean age of the sample was 24 years, ranging from 15 to 32 . These participants were selected from among a large sample of 340 EFL learners after taking the quick oxford placement test. Both males and females learners participated in the study. There were 6 male and 6 female teachers. Classes were either single-gendered or mixed gendered. Four of single-gendered classes were for boys which were taught by male teachers. The other four classes were for girls which conducted by female teachers. The other four classes were mixed-gendered; two males and two females taught the classes. Prior to assigning students to groups they were sit for QOPT. Availability was the main criteria of subject selection. However, classes were chosen in a way that equal number of single-gendered and mixed-gendered classes took part in the study.

\subsection{Instruments}

In order to conduct this research and answer the research question the Oxford Quick placement test and Tsui's (1994) framework were utilized. These instruments are explained in the following section in detail.

Oxford Quick Placement Test (OQPT) - The Oxford Quick Placement Test (OQPT) was used to measure the participants' language proficiency. The test consists of sixty items with different question formats comprising grammar, vocabulary, and 5 paragraphs of reading texts. There are multiple choice, item matching, and cloze test type items in the test. In each item there is a missing word for which there are four options. Students should find the correct item among these options. All of the chosen participants for the present study were able to pass the test with a score between 80-100 out of 100 and categorized to be at the same level according to the OPT results. The reason why the researcher of the study decided to utilize OPT as the students' measure of proficiency was due to the fact that the test is a standard test of proficiency, and its validity and reliability were assumed to be satisfactory.

Tsui's Framework - In order to analyze the patterns of interaction among participants in EFL classrooms, Tsui's (1994) framework was used. Tsui's framework was used as the theoretical framework of this study. Focusing on the linguistic features of conversation in relation to the context of situation in which the language is used, Tsui uses the criteria of "structural location" and "prospected response" and the concepts of act, move and exchange following Sinclair and Coulthard (1975) to analyze English conversation. According to Tsui (1994), three-part exchange made up of three moves (initiation, response and follow-up) is the basic unit of conversational organization whether in or out of the classroom. Each of these moves can be made up of more than one act. When a move consists of more than one act, then one of the acts is the main act that is called the 
Navabfard, F., \& Rezvani, E.

'head act' and carries the discourse function of the entire move. The class of acts occurring at the head of the initiating move can be categorized as initiating acts, that occurring at the head of responding move is named responding acts, and that occurring at the head of the follow up move can be identified as follow up acts. In turn, each of these classes of acts has their own subclasses.

\subsection{Procedure}

This study was conducted among Iranian upper-intermediate EFL learners learning English at Isfahan English language institutes. Two weeks before conducting the study, the OPT was administered, and based on the results, 120 upper-intermediate level participants were chosen as the sample to be studied. The process of data collection comprised of two steps. The first step focused on collecting data for the first research question; it included the observation of classes and video-recording the classroom conversations in which the researcher was present as a non-participant observer during data collection process. Totally, 12 classes were observed and these classes were chosen for data analysis based on the degree of comprehensibility and relevance. Each class lasted about 90 minutes. The classes were held three days a week for one month. Then the collected data were transcribed and coded to be investigated for the patterns of interaction.

\section{Results}

\subsection{Effect of Gender on Patterns of Teacher-student Interactions (Initiation)}

Initiating speech acts were counted and frequencies have been presented in Table 1.

\section{Table 1}

The Frequency and Percentage of Each Act Produced by Male and Female Teachers

\begin{tabular}{|c|c|c|c|c|c|c|c|}
\hline \multirow[b]{2}{*}{ Head Acts } & \multirow[b]{2}{*}{ Subclasses of Acts } & & \multicolumn{2}{|c|}{ S class } & \multicolumn{2}{|c|}{ Mixed classes } & \multirow[b]{2}{*}{ Total } \\
\hline & & & $\mathrm{F}$ & M & $\mathrm{F}$ & M & \\
\hline \multirow[t]{6}{*}{ Elicitations } & Elicit: agree & & $15(5.6 \%)$ & $20(7.5 \%)$ & $\begin{array}{c}118 \\
(44.5 \%)\end{array}$ & $\begin{array}{c}107 \\
(40.4 \%)\end{array}$ & $\begin{array}{c}265 \\
(100 \%)\end{array}$ \\
\hline & Elicit: repeat & & $10(6.9 \%)$ & $12(8.3 \%)$ & $\begin{array}{c}52 \\
(36.1 \%)\end{array}$ & $\begin{array}{c}70 \\
(48.6 \%)\end{array}$ & $\begin{array}{c}144 \\
(100 \%)\end{array}$ \\
\hline & Elicit: Confirm & & 4 & 5 & 8 & 10 & 27 \\
\hline & Elicit: Commit & & 6 & 4 & 3 & 2 & 15 \\
\hline & Elicit: Clarify & & 5 & 5 & 7 & 8 & 24 \\
\hline & Elicit: Inform & & 0 & 0 & 0 & 0 & 0 \\
\hline \multirow{5}{*}{ Requestives } & Request for Action & & 4 & 6 & 7 & 1 & 18 \\
\hline & Request for Permission & & 3 & 3 & 4 & 2 & 12 \\
\hline & Proposal & & 6 & 2 & 3 & 3 & 14 \\
\hline & Invite & & 5 & 5 & 12 & 10 & 32 \\
\hline & Offer & & 3 & 7 & 3 & 6 & 19 \\
\hline \multirow[t]{4}{*}{ Directives } & Mandatives & Instruction & 9 & 9 & 13 & 21 & 52 \\
\hline & & Threat & 2 & 4 & 0 & 0 & 6 \\
\hline & Advisives & Advice & 2 & 2 & 1 & 3 & 8 \\
\hline & & Warn & 3 & 2 & 1 & 0 & 6 \\
\hline \multirow[t]{7}{*}{ Informatives } & Assessment & Assessing & 0 & 0 & 1 & 6 & 8 \\
\hline & & Criticism & 12 & 4 & 16 & 11 & 43 \\
\hline & & Compliment & 0 & $2(3.4 \%)$ & $\begin{array}{c}15 \\
(25.4 \%)\end{array}$ & $\begin{array}{c}42 \\
(71.1 \%)\end{array}$ & $59(100 \%)$ \\
\hline & & Self-denigration & 0 & 0 & 2 & 0 & 2 \\
\hline & & Self-commendation & 0 & 2 & 1 & 1 & 4 \\
\hline & Report & & 2 & 5 & 1 & 1 & 9 \\
\hline & expressive & & 1 & 1 & 0 & 0 & 2 \\
\hline
\end{tabular}

According to the above table, as it can be seen, the most salient initiating acts were posed within the category of 'elicitation: agree and repeat'. Moreover, these two significant frequencies are related to eliciting for agreement and repetition; 265 and 144, respectively. So, both male and female teachers showed significant differences in using 'elicit: agree' and 'elicit: repeat' speech acts in mixed classes. Regarding the former, female 
Exploring the gender effect on the pattern of EFL teacher-student interaction

teacher used $44.5 \%$ of all the agreement and male teacher $40.4 \%$ of all the agreement. In total, $84.9 \%$ of the agreements were made in mixed classes. Also, $84.7 \%$ of the repetitions were made in mixed classes. The same speech acts are far less frequently used in single classes.

In addition, another point that seemed noteworthy lied in the category of 'Informative: Assessment: compliment'. Here, $96.5 \%$ of the compliments were made in mixed classes. While only $3.5 \%$ of the compliments were in single-gender classes. Here, $71.4 \%$ of the compliments were made by male teachers while $25 \%$ of them were made by female teachers. An analysis of the mixed classes showed that female teachers repeated utterances made by male students and showed agreements with ideas proposed by the male students more frequently than those made by the female students. The same stands true for mixed classes with male teachers.

In order to understand whether this difference was statistically significant, a Chi-square was run which investigated the association between teacher's gender and their use of discourse acts. Table 2 illustrates the results of this test.

\section{Table 2}

Chi-Square Test between Teacher's Gender and Use of Discourse Acts

\begin{tabular}{lllc}
\hline & Value & df & Asymp. Sig (2-sided) \\
\hline Person Chi- Square & 50.04 & 12 & .00 \\
\hline
\end{tabular}

As Table 2 shows, the significant value is $.000(p<.05)$. This means that the discourse acts used by male teacher was significantly different from the discourse acts used by female teachers.

Table 3

Teachers' Attention to Gender in Mixed Classes

\begin{tabular}{|c|c|c|c|}
\hline Speech act & Teachers' gender & Male teachers & Female teachers \\
\hline \multirow[t]{2}{*}{ Elicit Agree } & addressing males & $42(39 \%)$ & $89(75.4 \%)$ \\
\hline & Addressing females & $65(61 \%)$ & $29(24.5 \%)$ \\
\hline \multicolumn{2}{|c|}{ Total } & $107(100 \%)$ & $118(100 \%)$ \\
\hline \multirow[t]{2}{*}{ Elicit: Repeat } & addressing males & $18(25.7 \%)$ & $36(72 \%)$ \\
\hline & addressing females & $52(74.3 \%)$ & $14(28 \%)$ \\
\hline \multicolumn{2}{|c|}{ Total } & $70(100 \%)$ & $50(100 \%)$ \\
\hline
\end{tabular}

In the above table, female teachers addressed male students in their agreement utterances and repetitions $75.4 \%$ and $72 \%$, respectively. In comparison with their utterances addressed to male students, these frequencies are significant. On the other hand, male teachers addressed male students addressed females more than males. This can be seen in frequencies of agreeing and repeating (61\% and $71.3 \%)$.

Regarding compliment, it was evident more compliments were addressed to females. The following table shows this.

\section{Table 4}

Teachers' Attention to Gender in Mixed Classes

\begin{tabular}{|c|c|c|c|}
\hline & Teachers' gender & Female teachers & Male teachers \\
\hline \multirow[t]{3}{*}{ Compliment } & addressing males & $5(33 \%)$ & $12(28.5)$ \\
\hline & addressing Females & $10(67 \%)$ & $30(71.5 \%)$ \\
\hline & & $15(100 \%)$ & 100) \\
\hline
\end{tabular}

\section{Discussion and Conclusion}

Since the study paid attention to gender-related patterns of interaction in the Iranian EFL classroom, after analyzing the participants in terms of their proficiency level, it was revealed that all the 120 students were at the 
same level of proficiency. Then, regarding the effect of gender on patterns of Teacher-student Interactions which mostly focused on the initiating speech acts addressed by the teachers, it was revealed in chapter four that teachers used two subcategories of elicitation and one subcategory of informative in mixed-gender classes more than they used them in single-gender classes. These subcategories were 'agree' and 'repeat' in the former category and 'compliment' in the latter category.

Further, results indicated that teachers in mixed classes paid attention to the opposite sex more than they did it to the same sex. In other words, in mixed classes, it was seen that female teachers paid far more attention to male students while male teachers paid more attention to the female students. By attention here, it is meant the frequencies of repetition, agreement and compliment they used for the opposite sex. A probe into previous studies also indicates that most of previous studies have indicated that female and male teachers have different patterns of interaction in classrooms (Chavez, 2000).

Other studies have revealed that teacher's sex can also be an influential factor on the classroom patterns of interaction (Pringle \& Canada, 1995; Hatzichristoo \& Hopf, 1999; Duffy, Warren, \& Walsh, 2001). Teachers with dissimilar genders have classes with different features based on the studies that have been done in this area. For instance, the overall features of a class trained by a male teacher had quicker paces, sudden subject changes, much (excessive) teacher floor time and shorter, but more often, student trips. Female teachers were described as communicative facilitators and perhaps more tolerant of first language use. Female teachers were also defined as too forceful in selecting subjects and requesting a great number of questions mainly through intending smooth and continuing the informal movement (Chavez, 2000).

For instance, Rashidi and Naderi (2012) revealed that students' gender influenced on the type of patterns of interaction in the classroom. They reported that "pupils played an active part in bringing the gender differences in classroom interaction into being: boys are more likely than girls to create conditions where their contributions would be sought by teachers, and they are more likely than girls to push themselves forward when contributors are not explicitly selected (p. 33). In a similar vein, Tannen (1991) concluded that classroom patterns of interaction are affected by factors such as race, class context, and age differences along with sexual orientation, professional training, and individual personality. Similarly Jones (2000) revealed that unequal treatment of girls and boys can be decreased through training and self-analysis of video recordings of classroom teaching.

In addition, findings of Shomoossi, Amouzadeh, and Ketabi (2008) were in line with those of the present study. Their study sought to investigate classroom interaction with reference to gender and technology. Their findings indicated that the interaction patterns are gender-related to some extent. Also, the interaction pattern in the laboratory classes was similar to, but not the same as, the whole-class discussion patterns proposed in earlier literature. The present study concluded that gender of Iranian teachers have significant effects on the patterns of classroom interaction, questions and responses, and the types of feedback they used. In all the issues investigated, there was evidence that, firstly, mixed-gender classes were different from single-gender classes; secondly, Moreover, teachers paid more attention to the opposite gender in mixed-gender classes. Another conclusion was that teachers in the present study did not use other components of speech acts introduced in Tsui's framework. As it was revealed in result, only three components, namely 'elicit: repeat', 'elicit: agree' and 'informative: compliment' had fairly high frequencies and other components were not noted by the teacher both in single-gender and mixed-gender classrooms. Finally, regarding mixed-gender classrooms, it should be noted that Iranian teacher must pay fair amount of attention to both gender so as to avoid any traces of misunderstanding and discrimination.

\section{References}

Bakhtin, M. (1986). Speech genres and other late essays. Austin: University of Texas.

Bialystok, E. (1979). Explicit and implicit judgements of L2 grammaticality. Language Learning, 29(1), 81-103. https://doi.org/10.1111/j.1467-1770.1979.tb01053.x 
Exploring the gender effect on the pattern of EFL teacher-student interaction

Bruner, J. (1978). The role of dialogue in language acquisition. In A. Sinclair, R. J. Jarvelle, \& W. J. M. Levelt (Eds.), The child's conception of language (pp. 241-256). New York: Springer-Verlag.

Canada, K., \& Pringle, R. (1995). The role of gender in college classroom interactions: a social context approach. Sociology of Education, 68, 161-186. https://doi.org/10.2307/2112683

Cazden, C. (1980). Peekaboo as an instructional model: Discourse development at home and at school. Papers and Reports of Child Language Development, 17, 1-29.

Celce-Murcia, M. (1987). Teaching pronunciation as communication. In J. Morley (Ed.), Current perspectives on pronunciation: Practices anchored in theory (pp. 5-12). Washington, DC: TESOL.

Chavez, M. (2000). Teacher and student gender and peer group gender composition in German foreign language classroom discourse: An exploratory study. Journal of Pragmatics, 32, 1019-1058. https://doi.org/10.1016/S0378-2166(99)00065-X

Constantinou, P. (2008). Heightening our awareness of gender stereotypes. Strategies, 21(3), 28-34. https://doi.org/10.1080/08924562.2008.10590774

Doray, M. B. A. (2005). Gender differentiated discourse: A study of teacher discourse in the adult ESL classroom. Retrieved from http://espace.library.curtin.edu.au/R/?func=dbin-jump-full\&object_id=16608\&local_base=GEN01-ER $\underline{\mathrm{A} 02}$

Duffy, J., Warren, K., \& Walsh, M. (2001). Classroom interactions: Gender of teacher, gender of student, and classroom subject. Sex Roles, 45(9), 579-593. https://doi.org/10.1023/A:1014892408105

Eckert, P., \& McConnell-Ginet, S. (1992). Think practically and look locally: language and gender as community-based practice. Annual Review of Anthology, 21, 461-490. https://doi.org/10.1146/annurev.an.21.100192.002333

Gee, J. P. (2001). Literacy, discourse, and linguistics: Introduction and what is literacy? In E. Cushman, E. R. Kintgen, B. M. Kroll, \& M. Rose (Eds.), Literacy: A critical sourcebook (pp. 525-544). Boston, MA: Bedford/St. Martins.

Good, T. L., \& Brophy, J. E. (1990). Educational psychology: A realistic approach. Longman/Addison Wesley Longman.

Hall, R. (1982). The classroom climate: A chilly one for women? Association of American Colleges, Project on the status of women. Washington, DC.

Hashemi, M. (2012). The impact of gender on language learning strategies of Iranian EFL learners. International Journal of Academic Research, 3(2), 280-285.

Hopf, D., \& Hatzichristou, Ch. (1999). Teacher gender-related influences in Greek schools. British Journal of Educational Psychology, 69(1), 1-18. https://doi.org/10.1348/000709999157527

Jones, S. (2000). Seeing things differently: Teacher's Constructions of Underachievement. Gender and Education $16 / 4,531546$.

Kelly, G. J., \& Bazerman, C. (2003). How students argue scientific claims: A rhetorical-semantic analysis. Applied Linguistics, 24(1), 28-55. https://doi.org/10.1093/applin/24.1.28

Lakoff, R. (1975). Language and woman's place. New York: Harper and Row.

Lin, A. M. Y. (2007). What's the use of triadic dialogue? Activity theory, conversation analysis and analysis of pedagogical practices. Pedagogies, 2(2), 77-94. https://doi.org/10.1080/15544800701343943

Rashidi, N., \& Rafiee Rad, M. (2010). Analyzing patterns of classroom interaction in EFL classrooms in Iran. The Journal of Asia TEFL, 7(3), 93-120.

Romaine, S. (1999). Communicating gender. London: Lawrence Erlbaum Associates.

Sadker, D. (1999). Gender equity: Still knocking at the classroom door. Educational Leadership, 56(7), 22-26.

Sadker, M., \& Sadker, D. (1992). Ensuring equitable participation in college classes. In L. L. B. Border \& N. V. N. Chism (Eds.), Teaching for diversity: New directions for teaching and learning (Vol. 49, pp. 49-56)

San Francisco: Jossey-Bass. https://doi.org/10.1002/t1.37219924906

Shomoossi, N., \& Amouzadeh M., \& Ketabi, S. (2008). Classroom interaction mediated by gender and technology: The language laboratory course. Novitas-ROYAL, 2(2), 176-184.

Simpson, A. (1997). It's a game! The construction of gendered subjectivity. In R. Wodak (Ed.), Gender and 
Navabfard, F., \& Rezvani, E.

discourse (pp. 197-224). London: Sage Publications. https://doi.org/10.4135/9781446250204.n9

Sinclair, J., \& Coulthard, R. M. (1975). Toward an analysis of discourse. The English used by teachers and pupils. Oxford, UK: Oxford University Press.

Spender, D. (1980). Man-made language. London: Routledge.

Spender, D. (1982). Invisible women: The schooling scandal. London: Writers and Readers Publishing Co-operative Society with Chameleon Editorial Group.

Talbot, M. (1998). Language and gender: An introduction. Cambridge: Polity Press.

Tannen, D. (1991). Teacher's classroom strategies should recognize that males and females use language differently. Chronicle of Higher Education, 37, B1.

Thorne, B. (1979). Claiming verbal space: women speech and language for college classrooms. Paper presented at the Research Conference on Educational Environments and Undergraduate Women, Wellesley College, Wellesley, MA.

Tsui, A.B.M. (1994). English Conversation. Oxford University Press, Oxford 